\title{
Preface to Special Issue of Chinese Journal of Catalysis in honor of the 90th birthday of Professor Enze Min
}

This special issue is dedicated to Professor Enze Min on the occasion of his 90th birthday. It is in recognition of his outstanding contributions to many aspects in the fields of applied catalysis and chemical engineering.

Professor Min was born on February 8, 1924 in Chengdu, Sichuan Province, China. He earned his B.S. degree in Chemical Engineering at the National Central University in 1946. He then went to the United States, where he obtained his M.S. (1948) and Ph.D (1951) degrees, under the guidance of Professor J. H. Koffolt from The Ohio State University. After spending four years as a Senior Chemical Engineer at the Nalco Chemical Company in Chicago, he returned to China in 1955 and joined the Research Institute of Petroleum Processing.

Over the past five decades, Professor Min has been developing novel oil refining catalysts. His research has been instrumental in supplying the technical foundations for manufacturing petroleum-processing catalysts, and for promoting the rapid growth and development of the oil refining industry in China. His research projects have focused on fabricating novel catalytic materials that have led to numerous applications in the area of catalyst and process technologies. Throughout his career, he has been an active supporter of green chemistry projects, and has successfully investigated many environmentally-friendly chemical processes and technologies in China. He has constantly supported the sustainable development of catalytic science and technology for petroleum refining and petrochemical industry in China. He has co-authored research papers and published several influential books. He is an excellent teacher and has been a mentor to many talented graduate students, scientists, and engineers in China's petroleum refining and petrochemical industry.

Professor Min has received numerous prizes, awards, and honors. He was elected to the Chinese Academy of Sciences in 1980, the Academy of Sciences for the Developing World in 1993, and the Chinese Academy of Engineering in 1994. He received the "Distinguished Alumni Award" from The Ohio State University in 1983 and 1989, and the Prize for Scientific and Technological Progress from the Ho Leung Ho Li Founda- tion in 1994. In 2006, he was the inaugural recipient of the China Catalysis Achievement Award and in 2007 he won the State Supreme Science and Technology Award. Because of his remarkable achievements, he has received wide recognition as the founder of applied catalytic science for petroleum refining, the forerunner of independent innovation of petrochemical technology and a pioneer in the area of green chemistry in China.

Professor Min has been active in both domestic and international academic activities. He has served as Vice President, Chief Engineer, and Chairman of the Academic Committee at the Research Institute of Petroleum Processing, and also Chairman of the Academic Degree Conferment Committee at the China Petroleum and Chemicals Corporation. He has served as Deputy Director of the Division of Chemistry at the Chinese Academy of Sciences. He was the inaugural Chairman of the Chinese Catalysis Society and the Chairman of the Committee of Green Chemistry at the Chinese Chemical Society. He was on the Editorial Board of many scientific journals, such as Applied Catalysis. He has initiated numerous academic collaborations and partnerships, such as chaired the 21st Thematic Forum-Research program of the 14th World Petroleum Congress and co-chaired the 15th International Zeolite Conference.

This special issue honors Professor Min as he approaches his 90th birthday. He remains active and energetic, and continues to lead and inspire us to explore novel catalytic science and develop new catalytic technologies in the areas of petroleum refining, petrochemicals, and green chemistry. It is with our greatest respects that we wish Professor Min and his wife (Professor Wanzhen Lu, also a Member of the Chinese Academy of Sciences) longevity with great health.

The majority of the 25-invited articles in this special issue are from Professor Min's former graduate students, collaborators, colleagues, and friends. These articles reflect to some extent the wide research interests of Professor Min, and the current worldwide research frontiers and developments in the field of catalytic science and technology. We are very grateful to the authors, the reviewers, and the editorial office staff of Chi- 
nese Journal of Catalysis for their contributions and support.

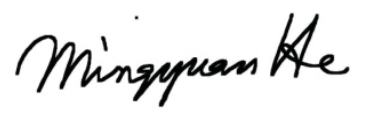

Mingyuan He (何鸣元)

Research Institute of Petroleum Processing

Beijing 100083, China

E-mail address: hemingyuan@ripp-sinopec.com

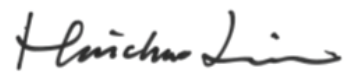

Haichao Liu (刘海超)

College of Chemistry and Molecular Engineering Peking University

Beijing 100871, China

E-mail address: hcliu@pku.edu.cn

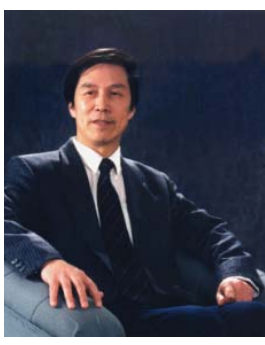

Professor Mingyuan $\mathrm{He}$ is Vice Chairman of Academic Committee, Research Institute of Petroleum Processing, China Petroleum and Chemicals Corporation, and Professor in Chemistry Department, East China Normal University. He has made technological innovations in the field of catalytic materials for refining and petrochemicals production. He has made contributions in technological progresses to heavy oil cracking, FCC gasoline octane enhancement, new spec gasoline production, etc. One of his achievements was elected as one of the "Nation's Top Ten Scientific and Technological
Achievements" in 1996. He was Co-Chair of 15th International Zeolite Conference, Chair of one forum for 16th World Petroleum Congress, and a member of Editorial Board of Applied Catalysis A: General. In 2000, he has been appointed as Principal Scientist for the State Key Basic Research Program in the field of green chemistry. In 2007, he has been elected as Vice President of International Zeolite Association. He has won numerous awards, prizes, and honors. He received Award from Ho Leung Ho Li Foundation, Hong Kong, in 2001, and the China Catalysis Achievement Award in 2012. He was elected Member of Chinese Academy of Sciences in 1995.

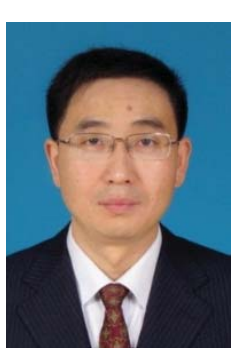

Professor Haichao Liu received his B.S. and M.S. degree from Sichuan University in 1990 and 1993, respectively, and his Ph.D degree from Research Institute of Petroleum Processing in 1996. From 1997 to 2003, he did postdoctoral research at The University of Tokyo, and The University of California at Berkeley. At the end of 2003, he joined the faculty of Peking University. His research interests currently focus on molecular catalysis and energy chemistry with emphasis on design of new catalysts and control of reaction pathways for selective conversion of biomass and its derivatives, etc. He is a recipient of Program for New Century Excellent Talents in University of the Chinese Ministry of Education in 2005, and National Science Fund for Distinguished Young Scholars of China in 2008. He received The Distinguished Lectureship Award from The Chemical Society of Japan in 2009, and The National Catalysis Prize for Young Scientists of China in 2012.

\title{
《催化学报》以本期专刊的出版庆祝闵恩泽院士九十华诞
}

\author{
何鸣元 ${ }^{\mathrm{a}}$, 刘海超 ${ }^{\mathrm{b}}$ \\ a中国石化石油化工科学研究院, 北京 100083 \\ ${ }^{b}$ 北京大学化学与分子工程学院, 北京100871
}

闵恩泽先生1924年2月出生于四川省成都市, 1946 年毕业于国立中央大学化工系, 获得学士学位, 1951年 毕业于美国俄亥俄州立大学化工系, 获得博士学位, 1955年回国到石油化工科学研究院工作. 五十多年来, 闵先生一直致力于石油炼制与石油化工科学技术的研 究. 他长期在炼油催化剂领域广泛而深入的研究, 奠定了 石油炼制催化剂制造技术的基础，支撑了我国炼油工业 的快速发展; 他自主创新, 开发新催化材料和新反应工 程技术, 为石油化工技术创新提供了 “ 新式武器” ; 他率 先倡导并组织在我国开展绿色化学研究, 开发了多项绿 色化学新工艺和新技术, 为我国石油炼制和石油化工催 化技术的可持续发展做出了突出的贡献. 五十多年来, 闵 先生不断总结科研规律, 著书立说, 为我国石油化工科技 和工业培养了大批创新人才.
五十多年来, 闵先生获得了许多学术奖励和荣誉. 他 先后当选中国科学院院士(1980)、发展中国家科学院院 士(1993)和中国工程院院士(1994). 他曾获得俄亥俄州 立大学 “杰出校友奖” $(1983,1989)$, 首届何梁何利科学 技术进步奖(1994), 首届中国催化成就奖(2006)和2007 年度国家最高科学技术奖等,被誉为 “我国炼油催化应 用科学的奠基人，石油化工技术自主创新的先行者，绿 色化学的开拓者”, 在国内外石油化工界享有崇高的声 誉.

五十多年来, 闵先生担任了许多学术职务, 积极推动 学术活动和学术交流. 他曾任石油化工科学研究院总工 程师、副院长、学术委员会主任, 中国石化总公司学位 委员会主任, 中国科学院学部主席团成员、化学部副主 任, 中国石油学会副理事长, 中国化学会咨询工作委员会 
主任、催化委员会主任、绿色化学专业委员会主任, 催 化基础国家重点实验室学术委员会主任, 《Applied Catalysis》等学术刊物的编委等. 他曾组织第十四届世界石 油大会 “第21专题论坛一一研究”、第十五届国际分子 笁大会等学术会议.

“老瀷伏杤, 志在千里”.今天闵恩泽先生依然精神 警铩, 正继续引领我们在石油炼制催化、石油化工催化 和绿色化学等领域开拓创新. 在此, 我们对闵先生五十多
年来对我国催化及相关领域发展做出的卓越贡献表示 崇高的敬意, 并祝愿他及夫人陆婉珍院士健康长寿!

本期专刊收录了25篇学术论文, 主要来自闵恩泽先 生的学生、合作者、同事和朋友，一定程度上反映了闵 先生过去五十多年的研究兴趣, 并展现了当前国际催化 科学与技术研究前沿和进展. 在此, 我们衰心感谢论文作 者、审稿专家以及《催化学报》编辑部等相关人员所付 出的辛勤劳动和给予的大力支持. 